\begin{tabular}{c} 
Volume and Issues Obtainable at Center for Sustainability Research and Consultancy \\
Journal of Business and Social Review in Emerging Economies \\
ISSN: 2519-089X \& ISSN (E): 2519-0326 \\
Volume 7: Issue 2, June 2021 \\
CSRட \\
Journal homepage: www.publishing.globalcsrc.org/jbsee \\
\hline
\end{tabular}

\title{
The Role of Socio Economic Factors in Determining the Women Bargaining Power in Pakistan
}

Mariam Amjad, COMSATS University Islamabad, Lahore Campus, Pakistan Ahmad Nawaz, Department of Economics, COMSATS University Islamabad, Lahore Campus, Pakistan

* Muhammad Masood Anwar, Women University of Azad Jammu Kashmir, Bagh, Pakistan Abdul Farooq, Department of Economics, COMSATS University Islamabad, Lahore Campus, Pakistan

*Corresponding author's email: smasood_ajk@yahoo.com

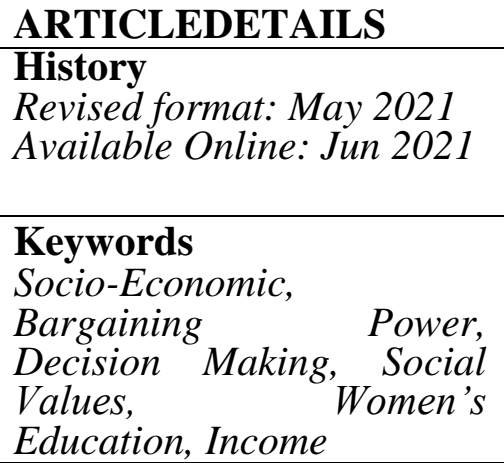

JEL Classification

$M 1, M 12$

\section{ABSTRACT}

Purpose: In recent times, women's status has been upgraded through an increase in socio-economic factors, which had implications in determining their bargaining power. The bargaining process produces household decisions which usually consist of unequal bargaining power. This study investigating the socio-economic factors through which female education and income change their bargaining power at the household.

Design/Methodology/Approach: For this purpose, a primary survey through a questionnaire has administered in different areas of Punjab, Pakistan. We have collected the data 200 working married women OLS ordinary least square model has been applied to estimate our results.

Findings: The result of the study shows that the socio-economic factors has significant and positive role in determining the women bargaining power within and outside the household. Higher income and education not only enhance their bargaining power in decision-making within and outside the household but also increase the status of women in society.

Implications/Originality/Value: Our society needs to change their prospective towards women by removing these obstacles and giving them freedom of voice and choice, so they can lead their life according to their will. Changing such social norms through education will create better position for women in the household as well in society.

(C)2021The authors, under a Creative Commons AttributionNonCommercial4.0

\footnotetext{
Recommended citation: Amjad, M., Nawaz, A., Anwar, M. M. and Farooq, A. (2021). The Role of Socio Economic Factors in Determining the Women Bargaining Power in Pakistan. Journal of Business and Social Review in Emerging Economies, 7(2), 467-480.
}

\section{Introduction}

Policy-makers and development practitioners believe that not only the well-being of women, but also the key development outcomes such as health and education have been affected by the 
bargaining power of women (Beegle, Frankenberg, \& Thomas, 2001; Qian, 2008; A. R. Quisumbing, 1994; Reggio, 2011) On the other hand, their bargaining power has an effect on decisions about household production like labor allocation for diverse activities which may include household chores, wage or agriculture work etc., (Alkire et al., 2013; Ganle, Afriyie, \&Segbefia, 2015; Mahmud \&Tasneem, 2014; Mello \&Schmink, 2017; Radel, Schmook, Haenn, $\&$ Green, 2017). Authority of the spouse in decision making process of household in resource allocation related to their bargaining power. Income has significant role to determine the bargaining power, but not only income can determine this many other factors also have influence on the bargaining process (C. Doss, 2013). Negotiation power over resources of household between spouses called the bargaining power. By using the ability of power and status influence the other, between spouses ones who make the household related decision possess more bargaining power in this process. It also includes household production decision such as labor allocation for various activities like agriculture work or wage etc., (Alkire et al., 2013; Ganle et al., 2015; Mello \&Schmink, 2017). Recently, participation of women in economic sector and labor force is a most highlighted topic, which reduces the gap between gender not only in employment sector but also in education. It has positive impact on economic growth (ILO, 2012). Higher education and employment are main factors for enhancing women status in society while giving them some power of bargaining power on resources. But discrimination still prevails in the society, the gap between gender pay is almost 14\% in OECD countries (OECD, 2018), all around the world, female participation in labor market is only 54\% as compared to males which is $81 \%$ (World Bank, 2017) Women have to bear care burden of their families which is hindrance in their way to participate in labor force (Folbre, 2018; Juhn\& McCue, 2017). Economic status of female and their earnings is an important indicator which supposed to positively related to the women bargaining power. In estimation, income can use as an instrumental variable or change in policy. Yusof and Duasa (2010) took indicator of women income share in income of household also Luke and Munshi (2011) took the sample of tea estates to estimation the change in female income in India.

\section{Background of the Study}

Usually males do not involve females in decision-making process within and outside the household (Ali et al., 2011; Zaman, Stewart, \&Zaman, 2006). Pakistani society is known as male dominant society, here gender discrimination exists which create huge inequalities in having access to all kind of resources (Mumtaz, Salway, Waseem, \&Umer, 2003). Pakistani women are deprived of even the basic needs for their life like proper diet, education etc. They are not even allowed to participate in workforce and other social activities (Jejeebhoy\&Sathar, 2001; Winkvist\&Akhtar, 2000). Women status in the society is known only as homemakers and dependent members while men are known as wage earner. This kind of gender inequality, especially in developing countries such as India, Pakistan, Nepal, Bangladesh due to women unequal bargaining power within the house, which cause the uneven outcomes in well-being (Ngunjiri, 2013). Females are the major part of the rural economy in Pakistan. But still they remain unseen for their efforts and nobody acknowledged their importance. They just consider as a child bearer and care taker of the house. According to (UN, 2018) Worldly, Pakistan ranking is very low for gender equality.

All around the world, almost 865 million women have the potential to fully contribute towards their economies. From which 812 million women are of developing countries. In Pakistan, the female participation rate in labor force was only $17.87 \%$ in 2004. Recently Pakistan shows a significant increase in female participation rate in labor force 22\% in 2019 (World Bank, 2019). 


\section{Literature Review}

The existing literature gives indication about the indicators of women bargaining power where the numbers of variables are used as proxies of bargaining power. Few authors have taken the women's role over consumption decisions of this as proxy for the bargaining power. Where the others highlight the assets held by women as instrumental in determining their bargaining power. There are many other factors exist that affect the outcomes of household decision making and expressed as the indicators of bargaining power. Previous literature about intra-household allocation provided the results that an extra dollar given to mother was supposed to spent on food, children' schooling and health than an extra dollar given to father (Thomas, 1994). Desai and Andrist (2010) gave their point of view on these issues in the Indian context and find response by experimenting for a positive relation between age at marriage and the three measures of empowerment which are: control over family resources, access to resources and involvement in household decisions. Yount (2005) examines about the Egyptian women's access to resources and their response on exposure to the new ideas on their empowerment and freedom. She uses direct measures of empowerment which includes women's attitude around a male child preference, household decision making including women who have the final say in the household about visiting friends and in the household spending about their children education, health care and marriage. All these results show that the urban working women, those who are educated, have greater hold and influence in making decisions for their children and have freedom to take decisions for their children. This indicates that giving new ideas improve the women's empowerment in Egypt. Most of the empirical literature of developing countries like Pakistan, Bangladesh and India emphasize that how the different factors effect female bargaining power within the household, such as education, family size, no of sons, family status, asset ownership, participation in paid employment (Sarikhani, 2012; Sathar\&Kazi, 2000). If female have a higher degree and income or asset ownership, these factors can ensure women status in society (Acharya, Bell, Simkhada, Van Teijlingen, \&Regmi, 2010; Arooj et al., 2013; Fatima, 2014). Female with more land / assets have more authority in household.

Guvuriro and Booysen (2018) examine the elements of the intra household decision making power and responsibilities the women of the South African couples. In this study they also show the impact of the financial decision making and bargaining power on the household goods and their spending on them. The results show the gap in the income, age, and career that support a female spouse endorses their financial decision making as well. And if the female partner financial decision making is greater than they will do larger expenditures on household type goods, food, and education disregarding to the male partners. Shahid (2017) investigates domestic negotiation power between male and female of Pakistani families in Houston. The bargaining power used as strategy by immigrant women of Pakistan in U.S. They examine that these immigrant women bargaining strategies tried to fulfill their needs and also access to healthcare facilities. It shows who holds the power of decision making of resources distribution within and outside the household. The findings show that the more income and education have positive and significant impact on female decision making and negotiation power. But wife natal family background and permanent residency are also important determinants of their negotiation and decision-making power.

Education plays a vigorous role in the processes of decision making and resource allocation. Education not only impacts the outside options of women but also her bargaining power. Women education relative to her husband may attached towards her bargaining power. Thomas (1994) takes education level of her and her husband to check the impact of it on child height for age. A. Quisumbing, Estudillo, and Otsuka (2004) also take level of education of both spouses to examine the education level of children and transfer of land to children in Ghana, the Philippines, and Indonesia. Moghadam, Khiaban, Esmaeili, and Salsali (2018) international research shows 
that increasing level of women education had significant impact to decrease fertility rate. This phenomenon has also prevailed in Iran by decreasing fertility rate in recent decades. Higher level of education in Iranian women has decreased their fertility rate. To investigate this study, they used a narrative review method. They examine that the higher number of women in universities decreases their fertility rate, but they are still deprived from power of decision-making within and outside the household. The research also shows that the increasing level of education does not lead towards gender equality regarding their socio-economic, political and cultural status. They suggest that the women's empowerment one of the main determinants for sustainable development. So, it is need of the time to make some strategy to decrease gender inequality and more emphasis on women rights.

In the literature, income and education are highlighted as an important indicator of bargaining power along with many other proxies (C. R. Doss, Deere, Oduro, \&Swaminathan, 2011). However, women's beliefs and perceptions about their rights and role in society, social values, political values, and their freedom and choice are proxies of their bargaining power. There is a dearth of literature which empirically link those non-income dimension of bargaining power in the context of the Pakistan. Therefore, the purpose of this study is to fill the Gap by examining the impact of women's education and income on their bargaining power, taking in account a comprehensive set of proxies of bargaining power. Further, the underlying study utilizes larger sample size taking into account broader section of working women in a society.

\section{Methodology}

The research methods to be used or chosen in the proposed study includes research design, data gathering process and the techniques for the data analysis. The underlying study is quantitative in nature utilizing a primary data set. It investigates the effects of socio-economic class primarily household income and education levels of working women in determining their bargaining power.

\section{Data and Sources}

The questionnaire composed of Twenty-three questions in total including sub categories of each question. The semi structured questionnaire was developed by consulting various studies carried out in this area and after discussion with academia questionnaire covering numerous variables. The population of the present study comprised of the working-women both from formal and informal sectors. In this study, the data collected from two hundred working married women divided in terms of income to five strata's lower, lower, middle, upper middle and upper-income groups. The data collected in the month of August till October 2018. The researcher had travelled in various areas of Lahore including universities, colleges, banks and beauty salons for collecting the data in the month of August. The women working in informal sector as domestic helpers, and tailors, beauticians and sales girls are also part of the sample. The final sample comprised only 180 out of 200 responses recorded to draw analysis of the research.

\section{Description of Variables}

Bargaining power is used as a dependent variable in this study while Income and Education are taken as independent variables of the study. Control variables are also used in this study. Control variables include size of family, age of women at the time of marriage, no. of children, dowry, children outcome, decision making, social mobility, social values, participation in politics, household income, no. of dependent, owner of house and family head. Women's bargaining power gives them power of making decision in house and strengthen their status in society. Many studies of the women's bargaining focus on husband and wife relationship (C. Doss, 2013). We used bargaining-index to measure the socio-economic factors impact on bargaining power in bargaining-index have taken the average of different components of the bargaining power to investigate the impact of socio-economic factors on the bargaining power. These components are 
Decision making (Connelly, Roberts, \&Zheng, 2010; Garikipati, 2008), Social Mobility (Breuer \&Asiedu, 2017; Sanyal, 2009), Social Values (Hanson, 2009; SebertKuhlmann et al., 2017; Yount\& Li, 2009, 2010), Participation of women in politics (Mahmud \&Tasneem, 2014; Sanyal, 2009), Financial empowerment (C. Doss, 2006; Haile, Bock, \&Folmer, 2012; Panda \&Agarwal, 2005), savings (Ashraf, Karlan, \& Yin, 2010; C. R. Doss, 1996; Lundberg \& Ward-Batts, 2000).

\section{Econometric Model}

Bargaining power $=\mathrm{f}$ (Income, Education, control variables $) \ldots$ (A)

Control variable includes size of family, age of women at the time of marriage, number of children, assets brought to marriage, first baby (boy or girl), number of dependent, earners, owner of house and family head.

\section{Bargaining Power}

Given below is the functional form of the equation (A)

Bargaining Index $=\beta_{0}+\beta_{1}$ (Income $)+\beta_{2}$ (Education) $+\beta_{3}$ (Control variables) $\ldots$ (1)

Bargaining Index: Decision making, social mobility, Social values, Political participation, financial empowerment, $\mathrm{DM}=$ Decision making, $\mathrm{SM}=$ Social mobility, $\mathrm{SV}=$ Social values, $\mathrm{PP}=$ Political participation, $\mathrm{FE}=$ Financial empowerment, EDU=Education, $\mathrm{INC}=$ Income, $\mathrm{S}=$ Savings.

$D M_{i}=\beta_{o}+\beta_{1} E D U_{i}+\beta_{2} I N C_{i}+\beta_{3} X_{i}+\varepsilon_{i} \ldots$ (1.1)

$S M_{i}=\beta_{o}+\beta_{1} E D U_{i}+\beta_{2} I N C_{i}+\beta_{3} X_{i}+\varepsilon_{i} \ldots(1.2)$

$S V_{i}=\beta_{o}+\beta_{1} E D U_{i}+\beta_{2} I N C_{i}+\beta_{3} X_{i}+\varepsilon_{i} \ldots(1.3)$

$P P_{i}=\beta_{o}+\beta_{1} E D U_{i}+\beta_{2} I N C_{i}+\beta_{3} X_{i}+\varepsilon_{i} \ldots(1.4)$

$F E_{i}=\beta_{o}+\beta_{1} E D U_{i}+\beta_{2} I N C_{i}+\beta_{3} X_{i}+\varepsilon_{i} \ldots(1.5)$

Bargaining Index $=\beta_{0}+\beta_{1}($ Income $)+\beta_{2}$ (Education $)+\beta_{3}($ Financial Empowerment $)+$ $\beta_{4}$ (Control variables) ... (2)

$$
\begin{aligned}
& D M_{i}=\beta_{o}+\beta_{1} E D U_{i}+\beta_{2} I N C_{i}+\beta_{3} F E_{i}+\beta_{4} X_{i}+\varepsilon_{i} \ldots \\
& S M_{i}=\beta_{o}+\beta_{1} E D U_{i}+\beta_{2} I N C_{i}+\beta_{3} F E_{i}+\beta_{4} X_{i}+\varepsilon_{i} \ldots \\
& S V_{i}=\beta_{o}+\beta_{1} E D U_{i}+\beta_{2} I N C_{i}+\beta_{3} F E_{i}+\beta_{4} X_{i}+\varepsilon_{i} \ldots \\
& P P_{i}=\beta_{o}+\beta_{1} E D U_{i}+\beta_{2} I N C_{i}+\beta_{3} F E_{i}+\beta_{4} X_{i}+\varepsilon_{i} \ldots
\end{aligned}
$$

Bargaining Index $=\beta_{0}+\beta_{1}($ Income $)+\beta_{2}($ Education $)+\beta_{3}($ Savings $)+\beta_{4}($ Control variables $) \ldots$ (3)

$$
\begin{aligned}
& D M_{i}=\beta_{o}+\beta_{1} E D U_{i}+\beta_{2} I N C_{i}+\beta_{3} S_{i}+\beta_{4} X_{i}+\varepsilon_{i} \ldots \\
& S M_{i}=\beta_{o}+\beta_{1} E D U_{i}+\beta_{2} I N C_{i}+\beta_{3} S_{i}+\beta_{4} X_{i}+\varepsilon_{i} \ldots \\
& S V_{i}=\beta_{o}+\beta_{1} E D U_{i}+\beta_{2} I N C_{i}+\beta_{3} S_{i}+\beta_{4} X_{i}+\varepsilon_{i} \ldots \\
& P P_{i}=\beta_{o}+\beta_{1} E D U_{i}+\beta_{2} I N C_{i}+\beta_{3} S_{i}+\beta_{4} X_{i}+\varepsilon_{i} \ldots \\
& F E_{i}=\beta_{o}+\beta_{1} E D U_{i}+\beta_{2} I N C_{i}+\beta_{3} S_{i}+\beta_{4} X_{i}+\varepsilon_{i} \ldots
\end{aligned}
$$


Table .1:Descriptive Statistics

\begin{tabular}{|c|c|c|c|c|c|}
\hline Variables & Obs. & Mean & Std. Dev. & Maximum & Minimum \\
\hline Age & 180 & 36.74444 & 8.692848 & 60 & 20 \\
\hline Education & 180 & 14.80556 & 4.630597 & 23 & 0 \\
\hline Children & 180 & 2.438889 & 1.536025 & 6 & 0 \\
\hline Household Size & 180 & 5.722222 & 1.818759 & 12 & 1 \\
\hline Dependents & 180 & 2.55 & 1.648683 & 7 & 0 \\
\hline Age at Marriage & 180 & 23.73889 & 3.878553 & 38 & 14 \\
\hline Earners & 180 & 2.394444 & .8489048 & 7 & 1 \\
\hline Share in Income & 180 & .4482222 & .2679701 & 1 & 0 \\
\hline Decision Making & 180 & 2.719048 & .7285722 & 4 & 1 \\
\hline Social Mobility & 180 & 2.603704 & .6761788 & 4 & 1 \\
\hline Social Values & 180 & 2.872222 & .4756974 & 4 & 1.333333 \\
\hline Political Participation & 180 & 2.561111 & .6279246 & 3.75 & 1 \\
\hline Bride Price & 180 & 765833.3 & 915480.4 & 5000000 & 8000 \\
\hline Bargaining Index & 180 & 2.45194 & .4571916 & 3.434524 & 1.25 \\
\hline
\end{tabular}

Source: Authors own calculation

Table. 1 shows the independent and dependent variables descriptive analysis which contains in this study. The total observations of the working women are 180. The average value of women age is 36.74 while standard deviation is 8.69 , which means the actual age of women is deviated by 8.69 from average value of age. The maximum values of age are 60 whereas minimum value of 20. The average value of education is 14.80 deviated by 4.63 where maximum value is 23 and the minimum value of the education is 0 . The mean value of the children is 2.43 deviated by 1.53 with the maximum value of 6 and the minimum value of 0 . The average value of the household size is 5.72 deviated by 1.81 where the maximum value is 12 and the minimum value is 1 . The mean value of the dependents is 2.55 deviated by 1.64 with the maximum value of 7 and the minimum value of 0 . The mean value of the age at marriage is 23.73 deviated by 3.87 with the maximum value of 38 and minimum value of 14. Average value of the earners is 2.39 where the maximum value is 7 and the minimum value is 1 . The mean value of the share in income is $0.44 \%$ deviated by 0.26 with the maximum value of 1 to minimum value of 0 . The mean value of the decision making is $2.71 \%$ deviated by 0.72 with the maximum of 4 and the minimum value of 1. The mean value of the social mobility is $2.60 \%$ deviated by 0.67 with the maximum value of 4 to minimum value of 1 . The mean value of the social values is $2.87 \%$ deviated by 0.47 with the maximum value is 4 and minimum value is $1.3 \%$. The mean value of the political participation is $2.56 \%$ deviated by 0.63 with the maximum value of 3.75 and the minimum value of 1 . The mean value of the bride price is 765833.3 deviated by 915480.4 with the maximum value of $50,00,000$ to minimum value of 8000 . The mean value of the bargaining-index is $2.45 \%$ deviated by 0.45 with the maximum value of $3.43 \%$ to minimum value of $1.25 \%$.

\section{Empirical Analysis}

We used OLS ordinary least square model in our study to examine the effect of independent variables on dependent variables. To control the problem of heteroscedasticity, we have used the 
robust regressions.

Hypothesis 1: Socio-economic factors do significantly affect the bargaining power and its components.

Table 2: Socio-Economic Factors and Bargaining Power

\begin{tabular}{|c|c|c|c|c|c|c|}
\hline & (1) & (2) & (3) & (4) & (5) & (6) \\
\hline Variables & Barg_index & $\begin{array}{l}\text { Decision } \\
\text { making }\end{array}$ & $\begin{array}{l}\text { Social } \\
\text { mobility }\end{array}$ & $\begin{array}{l}\text { Social } \\
\text { values }\end{array}$ & $\begin{array}{l}\text { Political } \\
\text { participatio } \\
\text { n }\end{array}$ & $\begin{array}{l}\text { Financial } \\
\text { empowerme } \\
\text { nt }\end{array}$ \\
\hline Education & $\begin{array}{l}0.0333 * * * \\
(0.0114)\end{array}$ & $\begin{array}{l}0.0630 * * * \\
(0.0219)\end{array}$ & $\begin{array}{l}0.0210 \\
(0.0214)\end{array}$ & $\begin{array}{l}0.0162 \\
(0.0195)\end{array}$ & $\begin{array}{l}-0.00402 \\
(0.0199)\end{array}$ & $\begin{array}{l}0.0529 * \\
(0.0299)\end{array}$ \\
\hline Share in income & $\begin{array}{l}-0.346^{* *} \\
(0.141)\end{array}$ & $\begin{array}{l}0.543 * * \\
(0.247)\end{array}$ & $\begin{array}{l}-0.362 \\
(0.231)\end{array}$ & $\begin{array}{l}-0.141 \\
(0.186)\end{array}$ & $\begin{array}{l}-0.502 * * \\
(0.234)\end{array}$ & $\begin{array}{l}-0.893 * * \\
(0.347)\end{array}$ \\
\hline Age & $\begin{array}{l}0.0180 * * * \\
(0.00353)\end{array}$ & $\begin{array}{l}0.0298 * * * \\
(0.00595)\end{array}$ & $\begin{array}{l}0.0244 * * * \\
(0.00629)\end{array}$ & $\begin{array}{l}-0.00572 \\
(0.00471)\end{array}$ & $\begin{array}{l}0.00734 \\
(0.00772)\end{array}$ & $\begin{array}{l}0.0248 * * \\
(0.00959)\end{array}$ \\
\hline Children & $\begin{array}{l}-0.0180 \\
(0.0302)\end{array}$ & $\begin{array}{l}-0.0510 \\
(0.0462)\end{array}$ & $\begin{array}{l}0.00581 \\
(0.0501)\end{array}$ & $\begin{array}{l}0.00496 \\
(0.0409)\end{array}$ & $\begin{array}{l}-0.0814 \\
(0.0515)\end{array}$ & $\begin{array}{l}0.0293 \\
(0.0724)\end{array}$ \\
\hline Hh size & $\begin{array}{l}-0.0182 \\
(0.0254)\end{array}$ & $\begin{array}{l}-0.00409 \\
(0.0334)\end{array}$ & $\begin{array}{l}-0.00330 \\
(0.0361)\end{array}$ & $\begin{array}{l}-0.00593 \\
(0.0255)\end{array}$ & $\begin{array}{l}-0.0167 \\
(0.0332)\end{array}$ & $\begin{array}{l}-0.0312 \\
(0.0515)\end{array}$ \\
\hline Hh head & $\begin{array}{l}0.00829 \\
(0.0875)\end{array}$ & $\begin{array}{l}0.130 \\
(0.167)\end{array}$ & $\begin{array}{l}-0.0136 \\
(0.148)\end{array}$ & $\begin{array}{l}0.119 \\
(0.119)\end{array}$ & $\begin{array}{l}-0.0445 \\
(0.128)\end{array}$ & $\begin{array}{l}-0.0177 \\
(0.249)\end{array}$ \\
\hline Age at marriage & $\begin{array}{l}0.000982 \\
(0.00993)\end{array}$ & $\begin{array}{l}0.000164 \\
(0.0174)\end{array}$ & $\begin{array}{l}0.00623 \\
(0.0171)\end{array}$ & $\begin{array}{l}-0.00852 \\
(0.0114)\end{array}$ & $\begin{array}{l}0.00630 \\
(0.0162)\end{array}$ & $\begin{array}{l}-0.0183 \\
(0.0241)\end{array}$ \\
\hline Dowry & $\begin{array}{l}06.56^{*} \\
(.0392)\end{array}$ & $\begin{array}{l}-04.07 \\
(.0577)\end{array}$ & $\begin{array}{l}-02.79 \\
(.0889)\end{array}$ & $\begin{array}{l}01.34 \\
(.0458)\end{array}$ & $\begin{array}{l}-01.53 \\
(.0545)\end{array}$ & $\begin{array}{l}03.18^{* * * *} \\
(.0704)\end{array}$ \\
\hline $\begin{array}{l}\text { 2.howner } \\
\text { (husband) }\end{array}$ & $\begin{array}{l}-0.196 * * \\
(0.0909)\end{array}$ & $\begin{array}{l}-0.0394 \\
(0.163)\end{array}$ & $\begin{array}{l}0.124 \\
(0.177)\end{array}$ & $\begin{array}{l}-0.0764 \\
(0.122)\end{array}$ & $\begin{array}{l}-0.0538 \\
(0.145)\end{array}$ & $\begin{array}{l}-0.842^{* * *} \\
(0.215)\end{array}$ \\
\hline $\begin{array}{l}\text { 3.howner (another } \\
\text { member) }\end{array}$ & $\begin{array}{l}-0.332 * * * \\
(0.106)\end{array}$ & $\begin{array}{l}-0.529 * * * \\
(0.180)\end{array}$ & $\begin{array}{l}-0.0342 \\
(0.190) \\
\end{array}$ & $\begin{array}{l}-0.0477 \\
(0.151) \\
\end{array}$ & $\begin{array}{l}-0.0650 \\
(0.168) \\
\end{array}$ & $\begin{array}{l}-1.004 * * * \\
(0.270) \\
\end{array}$ \\
\hline $\begin{array}{l}\begin{array}{l}\text { 4.howner } \\
\text { (rented) }\end{array} \\
\end{array}$ & $\begin{array}{l}-0.264 * * \\
(0.121) \\
\end{array}$ & $\begin{array}{l}-0.00187 \\
(0.241) \\
\end{array}$ & $\begin{array}{l}-0.0588 \\
(0.230) \\
\end{array}$ & $\begin{array}{l}0.0684 \\
(0.192) \\
\end{array}$ & $\begin{array}{l}0.139 \\
(0.233) \\
\end{array}$ & $\begin{array}{l}-1.206^{* * * *} \\
(0.309) \\
\end{array}$ \\
\hline 2.sector (private) & $\begin{array}{l}-0.141 * * \\
(0.0671)\end{array}$ & $\begin{array}{l}-0.142 \\
(0.106)\end{array}$ & $\begin{array}{l}-0.0788 \\
(0.115)\end{array}$ & $\begin{array}{l}-0.104 \\
(0.0821)\end{array}$ & $\begin{array}{l}-0.219 * * \\
(0.0983)\end{array}$ & $\begin{array}{l}-0.428 * * \\
(0.166)\end{array}$ \\
\hline $\begin{array}{l}\text { 3.sector } \\
\text { (informal) }\end{array}$ & $\begin{array}{l}0.0161 \\
(0.168)\end{array}$ & $\begin{array}{l}0.325 \\
(0.317)\end{array}$ & $\begin{array}{l}0.200 \\
(0.312)\end{array}$ & $\begin{array}{l}-0.0926 \\
(0.250)\end{array}$ & $\begin{array}{l}-0.354 \\
(0.224)\end{array}$ & $\begin{array}{l}-0.292 \\
(0.434)\end{array}$ \\
\hline First child & $\begin{array}{l}0.0294 \\
(0.0447)\end{array}$ & $\begin{array}{l}0.0426 \\
(0.0801)\end{array}$ & $\begin{array}{l}0.0565 \\
(0.0820)\end{array}$ & $\begin{array}{l}-0.0198 \\
(0.0604)\end{array}$ & $\begin{array}{l}0.0844 \\
(0.0755)\end{array}$ & $\begin{array}{l}-0.0239 \\
(0.121)\end{array}$ \\
\hline Constant & $\begin{array}{l}1.747 * * * \\
(0.365)\end{array}$ & $\begin{array}{l}0.548 \\
(0.606)\end{array}$ & $\begin{array}{l}1.325^{* *} \\
(0.639)\end{array}$ & $\begin{array}{l}\text { 3.113*** } \\
(0.460)\end{array}$ & $\begin{array}{l}2.845 * * * \\
(0.558)\end{array}$ & $\begin{array}{l}1.514 * \\
(0.891)\end{array}$ \\
\hline Observations & 180 & 180 & 180 & 180 & 180 & 180 \\
\hline Value of F & 12.57 & 6.89 & 3.39 & 1.00 & 1.88 & 14.09 \\
\hline Prob>F & 0.0000 & 0.0000 & 0.0001 & 0.4533 & 0.0321 & 0.0000 \\
\hline R-squared & 0.404 & 0.306 & 0.163 & 0.073 & 0.144 & 0.375 \\
\hline
\end{tabular}

In table 2, independent variables are related to the socio-economic factor. To the significance of the overall regression model, $\mathrm{F}$ test is used which is significant for all the regressions. Findings show that the education and income have the significant impact on bargaining power. In equation 1, education shows the positive impact on bargaining power, higher level of education determines the bargaining power. As women gain more education, they are able to increase their bargaining power within the household; the results are in line with the study of the (Acharya et al., 2010; De Brauw, Gilligan, Hoddinott, \& Roy, 2014; Kabeer, 1999; Kandiyoti, 1998) Income has the significant but negative impact on the bargaining power whereas, women with lower level of income contribute larger amount of their income in household relative to the higher level of income. Women with lower level of income have to face obstacles related to their bargaining power and decision making because they belong to the lower middle class where men are known as dominator and head of the house. If woman have a higher income than her husband does not 
mean that she has a higher level of empowerment (Miedema, Shwe, \&Kyaw, 2016). On the other hand, women with higher level of income have more freedom and power to make decisions, because they already belong to the upper class where they have no need to contribute more in household income. Dowry has positive and significant impact on bargaining power and financial empowerment shows that the assets brought to marriage enhance the women's status in household. High dowry establishes a strong position for women in the house and give her more power to negotiate (Jejeebhoy\&Sathar, 2001) dowry increase the women status in household and ensures her wellbeing (Zhang \& Chan, 1999) dowry positively impact on outcomes, and has an impact on household bargaining power. Which show, higher dowry or dowry is related with higher self-reported satisfaction of a women (Brown, 2009). In equation 2, now we separated the bargaining components from bargaining index. The independent variables are related to the dependent variable i.e. decision making. Share in income has positive and significant impact on decision making of purchasing small and large items. This shows that increase in income enhance the power of decision making in household. Again, education and age have positive and significant impact on decision making. Female ownership of a house has positive and significant impact on dependent variables. All other ownership had undermined the bargaining power except women ownership of house. Women with their own house have more bargaining power relative to the husband and rented (Beegle et al., 2001; Panda \&Agarwal, 2005). In equation 3 and 4 where dependent variables are social mobility and social values which are related to independent variables. In the equation 3 the socio-economic factors do not have significant impact, but age came out significant. Education also has positive and significant impact on financial empowerment in equation 6. Overall result shows that the socioeconomic factors do affect the bargaining power and its components.

Hypothesis 2: Financial empowerment does significantly affect bargaining power. 
Table.3 Financial Empowerment and Bargaining Power

\begin{tabular}{|c|c|c|c|c|c|}
\hline & $(1)$ & (2) & (3) & $(4)$ & (5) \\
\hline Variables & $\begin{array}{l}\text { Bargaining } \\
\text { Index }\end{array}$ & $\begin{array}{l}\text { Decision } \\
\text { making }\end{array}$ & $\begin{array}{l}\text { Social } \\
\text { mobility }\end{array}$ & Social values & $\begin{array}{l}\text { Political } \\
\text { participation }\end{array}$ \\
\hline Education & $\begin{array}{l}0.0222 * * * \\
(0.00849)\end{array}$ & $\begin{array}{l}0.0570 * * * \\
(0.0216)\end{array}$ & $\begin{array}{l}0.0105 \\
(0.0191)\end{array}$ & $\begin{array}{l}0.0145 \\
(0.0189)\end{array}$ & $\begin{array}{l}-0.0102 \\
(0.0201)\end{array}$ \\
\hline Share in income & $\begin{array}{l}-0.114 \\
(0.122)\end{array}$ & $\begin{array}{l}0.644 * * * \\
(0.242)\end{array}$ & $\begin{array}{l}-0.184 \\
(0.226)\end{array}$ & $\begin{array}{l}-0.112 \\
(0.201)\end{array}$ & $\begin{array}{l}-0.397 \\
(0.244)\end{array}$ \\
\hline $\begin{array}{l}\text { Financial } \\
\text { Empowerment }\end{array}$ & $\begin{array}{l}0.136 * * * \\
(0.0297)\end{array}$ & $\begin{array}{l}0.113 * * \\
(0.0545)\end{array}$ & $\begin{array}{l}0.199 * * * \\
(0.0587)\end{array}$ & $\begin{array}{l}0.0322 \\
(0.0449)\end{array}$ & $\begin{array}{l}0.118 * * \\
(0.0518)\end{array}$ \\
\hline Age & $\begin{array}{l}0.0133 * * * \\
(0.00361) \\
\end{array}$ & $\begin{array}{l}0.0270^{* * * *} \\
(0.00618)\end{array}$ & $\begin{array}{l}0.0195 * * * \\
(0.00653) \\
\end{array}$ & $\begin{array}{l}-0.00652 \\
(0.00491) \\
\end{array}$ & $\begin{array}{l}0.00442 \\
(0.00807)\end{array}$ \\
\hline Children & $\begin{array}{l}-0.0315 \\
(0.0276) \\
\end{array}$ & $\begin{array}{l}-0.0543 \\
(0.0458) \\
\end{array}$ & $\begin{array}{l}-3.72 \mathrm{e}-05 \\
(0.0488)\end{array}$ & $\begin{array}{l}0.00402 \\
(0.0408)\end{array}$ & $\begin{array}{l}-0.0849 \\
(0.0516)\end{array}$ \\
\hline Hh size & $\begin{array}{l}-0.0114 \\
(0.0199) \\
\end{array}$ & $\begin{array}{l}-0.000567 \\
(0.0325) \\
\end{array}$ & $\begin{array}{l}0.00292 \\
(0.0335) \\
\end{array}$ & $\begin{array}{l}-0.00493 \\
(0.0256) \\
\end{array}$ & $\begin{array}{l}-0.0131 \\
(0.0322) \\
\end{array}$ \\
\hline Hh head & $\begin{array}{l}0.0159 \\
(0.0755) \\
\end{array}$ & $\begin{array}{l}0.132 \\
(0.168) \\
\end{array}$ & $\begin{array}{l}-0.0101 \\
(0.134) \\
\end{array}$ & $\begin{array}{l}0.120 \\
(0.119) \\
\end{array}$ & $\begin{array}{l}-0.0425 \\
(0.121) \\
\end{array}$ \\
\hline Age at marriage & $\begin{array}{l}0.00732 \\
(0.00839) \\
\end{array}$ & $\begin{array}{l}0.00222 \\
(0.0170) \\
\end{array}$ & $\begin{array}{l}0.00987 \\
(0.0152) \\
\end{array}$ & $\begin{array}{l}-0.00793 \\
(0.0116) \\
\end{array}$ & $\begin{array}{l}0.00845 \\
(0.0163) \\
\end{array}$ \\
\hline Dowry & $\begin{array}{l}-02.83 \\
(.0378) \\
\end{array}$ & $\begin{array}{l}-04.00 \\
(.0611) \\
\end{array}$ & $\begin{array}{l}-09.13 \\
(.0881) \\
\end{array}$ & $\begin{array}{l}03.21 \\
(.0478) \\
\end{array}$ & $\begin{array}{l}-05.28 \\
(.0571) \\
\end{array}$ \\
\hline $\begin{array}{l}\text { 2.howner } \\
\text { (husband) }\end{array}$ & $\begin{array}{l}0.0482 \\
(0.0822) \\
\end{array}$ & $\begin{array}{l}0.0556 \\
(0.175) \\
\end{array}$ & $\begin{array}{l}0.292 * \\
(0.176) \\
\end{array}$ & $\begin{array}{l}-0.0493 \\
(0.129) \\
\end{array}$ & $\begin{array}{l}0.0453 \\
(0.141) \\
\end{array}$ \\
\hline $\begin{array}{l}\text { 3.howner } \\
\text { (another member) }\end{array}$ & $\begin{array}{l}-0.0610 \\
(0.0946) \\
\end{array}$ & $\begin{array}{l}-0.415^{* *} \\
(0.195) \\
\end{array}$ & $\begin{array}{l}0.166 \\
(0.184)\end{array}$ & $\begin{array}{l}-0.0154 \\
(0.161) \\
\end{array}$ & $\begin{array}{l}0.0531 \\
(0.162)\end{array}$ \\
\hline $\begin{array}{l}\text { 4.howner } \\
\text { (rented) }\end{array}$ & $\begin{array}{l}0.0887 \\
(0.115) \\
\end{array}$ & $\begin{array}{l}0.134 \\
(0.252) \\
\end{array}$ & $\begin{array}{l}0.182 \\
(0.226) \\
\end{array}$ & $\begin{array}{l}0.107 \\
(0.204) \\
\end{array}$ & $\begin{array}{l}0.281 \\
(0.236) \\
\end{array}$ \\
\hline $\begin{array}{l}2 . \text { sector } \\
\text { (private) }\end{array}$ & $\begin{array}{l}-0.0257 \\
(0.0593) \\
\end{array}$ & $\begin{array}{l}-0.0933 \\
(0.103) \\
\end{array}$ & $\begin{array}{l}0.00663 \\
(0.116) \\
\end{array}$ & $\begin{array}{l}-0.0905 \\
(0.0862)\end{array}$ & $\begin{array}{l}-0.169^{*} \\
(0.0990) \\
\end{array}$ \\
\hline $\begin{array}{l}\text { 3.sector } \\
\text { (informal) }\end{array}$ & $\begin{array}{l}0.118 \\
(0.125) \\
\end{array}$ & $\begin{array}{l}0.358 \\
(0.304) \\
\end{array}$ & $\begin{array}{l}0.258 \\
(0.279) \\
\end{array}$ & $\begin{array}{l}-0.0832 \\
(0.249) \\
\end{array}$ & $\begin{array}{l}-0.319 \\
(0.231) \\
\end{array}$ \\
\hline First child & $\begin{array}{l}0.0433 \\
(0.0399) \\
\end{array}$ & $\begin{array}{l}0.0453 \\
(0.0792) \\
\end{array}$ & $\begin{array}{l}0.0613 \\
(0.0808) \\
\end{array}$ & $\begin{array}{l}-0.0190 \\
(0.0606) \\
\end{array}$ & $\begin{array}{l}0.0872 \\
(0.0759) \\
\end{array}$ \\
\hline Constant & $\begin{array}{l}1.604 * * * \\
(0.300) \\
\end{array}$ & $\begin{array}{l}0.510 \\
(0.561) \\
\end{array}$ & $\begin{array}{l}1.013^{*} \\
(0.597) \\
\end{array}$ & $\begin{array}{l}3.184 * * * \\
(0.490) \\
\end{array}$ & $\begin{array}{l}2.624 * * * \\
(0.563) \\
\end{array}$ \\
\hline Observations & 180 & 180 & 180 & 180 & 180 \\
\hline Value of $F$ & 10.02 & 6.64 & 4.61 & 0.97 & 2.37 \\
\hline Prob $>F$ & 0.0000 & 0.0000 & 0.0000 & 0.4901 & 0.0041 \\
\hline R-squared & 0.416 & 0.324 & 0.228 & 0.076 & 0.170 \\
\hline
\end{tabular}

Table 3 we describe the impact of same set of independent variables over the different dependent variables accordingly. Now we can check the impact of financial empowerment as independent variable. In equation 1 and 2 education has positive and significant impact on bargaining power and decision making. Women education relative to her husband may enhance her bargaining power Share in income has positive and significant impact on decision making. Married women earnings are positively related with the authority of women in decision making (Arooj et al., 2013). Financial empowerment has positive and significant impact on bargaining, decisionmaking, social mobility and political participation. Findings show that the financial empowerment does determine the women status in the society. Women with assets and land have more power to make decision in house. It is highly correlated with the women bargaining power and significantly determines the bargaining power. To some extent financial empowerment as an independent variable has insignificant impact on share in income and education which means financial empowerment matter. Results show that the assets held by women determine their bargaining power. Assets of women are used to get various benefits and give more bargaining 
power (Beegle et al., 2001; C. Doss, 2006; Panda \&Agarwal, 2005). Age has positive and significant impact on bargaining, decision-making, and social mobility. Aging enhance the bargaining power of women and positively associated with decision making in household. Age one of the strongest determinants of the bargaining elder women have more power to take decision in the household (Acharya et al., 2010; Sarikhani, 2012; Sathar\&Kazi, 2000).

Hypothesis 3 :Savings do significantly determine the bargaining power.

Table.4 Savings and bargaining Power

\begin{tabular}{|c|c|c|c|c|c|c|}
\hline & (1) & $(2)$ & (3) & (4) & $(5)$ & (6) \\
\hline VARIABLES & $\begin{array}{l}\text { Bargaining. } \\
\text { index }\end{array}$ & $\begin{array}{l}\text { Decision } \\
\text { making }\end{array}$ & $\begin{array}{l}\text { Social } \\
\text { mobility }\end{array}$ & Social values & $\begin{array}{l}\text { Political } \\
\text { participation }\end{array}$ & $\begin{array}{l}\text { Financial } \\
\text { empowerme } \\
\text { nt }\end{array}$ \\
\hline Savings & $\begin{array}{l}0.0650 * \\
(0.0364)\end{array}$ & $\begin{array}{l}-0.00867 \\
(0.0587)\end{array}$ & $\begin{array}{l}0.0969 * \\
(0.0583)\end{array}$ & $\begin{array}{l}0.0473 \\
(0.0520)\end{array}$ & $\begin{array}{l}-0.0116 \\
(0.0596)\end{array}$ & $\begin{array}{l}0.254 * * * \\
(0.0826)\end{array}$ \\
\hline Education & $\begin{array}{l}0.0216 * \\
(0.0124)\end{array}$ & $\begin{array}{l}0.0680 \text { *** } \\
(0.0217)\end{array}$ & $\begin{array}{l}0.0168 \\
(0.0215)\end{array}$ & $\begin{array}{l}0.0153 \\
(0.0182)\end{array}$ & $\begin{array}{l}-0.00497 \\
(0.0184) \\
\end{array}$ & $\begin{array}{l}0.0380 \\
(0.0311)\end{array}$ \\
\hline Share in income & $\begin{array}{l}-0.324 * * \\
(0.146)\end{array}$ & $\begin{array}{l}0.422 * \\
(0.239)\end{array}$ & $\begin{array}{l}-0.284 \\
(0.233)\end{array}$ & $\begin{array}{l}-0.222 \\
(0.182)\end{array}$ & $\begin{array}{l}-0.466 * * \\
(0.236)\end{array}$ & $\begin{array}{l}-0.735 * * \\
(0.330)\end{array}$ \\
\hline Age & $\begin{array}{l}0.0122 * * * \\
(0.00419)\end{array}$ & $\begin{array}{l}0.0293 * * * \\
(0.00652)\end{array}$ & $\begin{array}{l}0.0226 * * * \\
(0.00626)\end{array}$ & $\begin{array}{l}-0.00773 \\
(0.00483)\end{array}$ & $\begin{array}{l}0.00885 \\
(0.00766)\end{array}$ & $\begin{array}{l}0.0177 * \\
(0.0100)\end{array}$ \\
\hline Earners & $\begin{array}{l}0.0149 \\
(0.0392)\end{array}$ & $\begin{array}{l}-0.125 * * \\
(0.0625)\end{array}$ & $\begin{array}{l}0.0214 \\
(0.0782)\end{array}$ & $\begin{array}{l}-0.0791 \\
(0.0542)\end{array}$ & $\begin{array}{l}0.127 * * \\
(0.0611)\end{array}$ & $\begin{array}{l}0.0317 \\
(0.0962)\end{array}$ \\
\hline Dependents & $\begin{array}{l}0.0356 \\
(0.0261)\end{array}$ & $\begin{array}{l}0.0585 \\
(0.0408)\end{array}$ & $\begin{array}{l}0.00482 \\
(0.0412)\end{array}$ & $\begin{array}{l}0.0519 \\
(0.0350)\end{array}$ & $\begin{array}{l}0.0365 \\
(0.0433)\end{array}$ & $\begin{array}{l}0.0159 \\
(0.0610)\end{array}$ \\
\hline Age at marriage & $\begin{array}{l}-0.00464 \\
(0.0103)\end{array}$ & $\begin{array}{l}-0.00478 \\
(0.0174)\end{array}$ & & $\begin{array}{l}-0.0128 \\
(0.0115)\end{array}$ & $\begin{array}{l}0.00314 \\
(0.0161)\end{array}$ & $\begin{array}{l}-0.0237 \\
(0.0239)\end{array}$ \\
\hline Children & $\begin{array}{l}-0.0405 \\
(0.0326)\end{array}$ & $\begin{array}{l}-0.0820 * \\
(0.0467)\end{array}$ & & $\begin{array}{l}-0.0281 \\
(0.0428)\end{array}$ & $\begin{array}{l}-0.0618 \\
(0.0518)\end{array}$ & $\begin{array}{l}0.0260 \\
(0.0692)\end{array}$ \\
\hline Hh size & $\begin{array}{l}-0.0292 \\
(0.0230)\end{array}$ & $\begin{array}{l}0.000740 \\
(0.0414)\end{array}$ & $\begin{array}{l}-0.00567 \\
(0.0405)\end{array}$ & $\begin{array}{l}-0.00590 \\
(0.0326)\end{array}$ & $\begin{array}{l}-0.0668 \\
(0.0415)\end{array}$ & $\begin{array}{l}-0.0332 \\
(0.0581)\end{array}$ \\
\hline $\begin{array}{l}\text { 2.howner } \\
\text { (husband) }\end{array}$ & $\begin{array}{l}-0.164 * * \\
(0.0828)\end{array}$ & $\begin{array}{l}-0.0988 \\
(0.145)\end{array}$ & $\begin{array}{l}0.145 \\
(0.160)\end{array}$ & $\begin{array}{l}-0.123 \\
(0.116)\end{array}$ & $\begin{array}{l}-0.0928 \\
(0.130)\end{array}$ & $\begin{array}{l}-0.790 * * * \\
(0.182)\end{array}$ \\
\hline $\begin{array}{l}\text { 3.howner } \\
\text { (another } \\
\text { member) }\end{array}$ & $\begin{array}{l}-0.288^{* * *} \\
(0.106)\end{array}$ & $\begin{array}{l}-0.505 * * * \\
(0.173)\end{array}$ & $\begin{array}{l}-0.0206 \\
(0.186)\end{array}$ & $\begin{array}{l}-0.0314 \\
(0.145)\end{array}$ & $\begin{array}{l}-0.164 \\
(0.158)\end{array}$ & $\begin{array}{l}-0.955 * * * \\
(0.266)\end{array}$ \\
\hline $\begin{array}{l}\text { 4.howner } \\
\text { (rented) }\end{array}$ & $\begin{array}{l}-0.137 \\
(0.136) \\
\end{array}$ & $\begin{array}{l}-0.0157 \\
(0.226)\end{array}$ & $\begin{array}{l}-0.0108 \\
(0.224)\end{array}$ & $\begin{array}{l}0.0569 \\
(0.188)\end{array}$ & $\begin{array}{l}0.114 \\
(0.232)\end{array}$ & $\begin{array}{l}-1.101 * * * \\
(0.307)\end{array}$ \\
\hline $\begin{array}{l}\text { 2.sector } \\
\text { (private) }\end{array}$ & $\begin{array}{l}-0.200 * * * \\
(0.0657)\end{array}$ & $\begin{array}{l}-0.143 \\
(0.108)\end{array}$ & $\begin{array}{l}-0.0918 \\
(0.113)\end{array}$ & $\begin{array}{l}-0.111 \\
(0.0776)\end{array}$ & $\begin{array}{l}-0.208 * * \\
(0.1000)\end{array}$ & $\begin{array}{l}-0.457 * * * \\
(0.160)\end{array}$ \\
\hline $\begin{array}{l}\text { 3.sector } \\
\text { (informal) }\end{array}$ & $\begin{array}{l}-0.127 \\
(0.182)\end{array}$ & $\begin{array}{l}0.355 \\
(0.306)\end{array}$ & $\begin{array}{l}0.162 \\
(0.320)\end{array}$ & $\begin{array}{l}-0.0948 \\
(0.241)\end{array}$ & $\begin{array}{l}-0.379 * \\
(0.209)\end{array}$ & $\begin{array}{l}-0.384 \\
(0.450)\end{array}$ \\
\hline Dowry & & $\begin{array}{l}-01.23 \\
(.0565)\end{array}$ & $\begin{array}{l}-03.64 \\
(.0864)\end{array}$ & $\begin{array}{l}-01.16 \\
(.0451)\end{array}$ & $\begin{array}{l}05.21 \\
(.0550)\end{array}$ & $\begin{array}{l}02.91 * * * \\
(.0676)\end{array}$ \\
\hline Constant & $\begin{array}{l}2.123 * * * \\
(0.367)\end{array}$ & $\begin{array}{l}1.123 * \\
(0.610)\end{array}$ & $\begin{array}{l}1.265 * * \\
(0.568)\end{array}$ & $\begin{array}{l}3.510 * * * \\
(0.488)\end{array}$ & $\begin{array}{l}2.821 * * * \\
(0.510)\end{array}$ & $\begin{array}{l}1.254 \\
(0.910)\end{array}$ \\
\hline Observations & 180 & 180 & 180 & 180 & 180 & 180 \\
\hline Value of F & 7.47 & 6.69 & 3.91 & 1.23 & 2.14 & 15.01 \\
\hline Prob>F & 0.0000 & 0.0000 & 0.0000 & 0.2515 & 0.0105 & 0.0000 \\
\hline R-squared & 0.339 & 0.323 & 0.175 & 0.101 & 0.159 & 0.410 \\
\hline
\end{tabular}

Robust standard errors in parentheses

In above table 4 in equation 1 savings has positive and significant impact on bargaining power which shows that the higher rate of savings tends toward the more bargaining power. Higher savings associated with higher women status in household. Savings does help to determine the bargaining power of the women in the house (Ashraf et al., 2010; C. R. Doss, 1996; Lundberg 
\&Ward-Batts, 2000). Education and age have positive and significant impact on bargaining power while share in income has negative and significant impact on bargaining power.

In equation 2 education, share in income and age have positive and significant impact on decision making process shows that the higher education high share in income and age do affect the decision making and give more power to women to make decisions (Acharya et al., 2010; Ganle et al., 2015). Earners has negative and significant impact on decision making indicates that increased number of earners in the house lessen the power of women in decision making. Children and house owner also have negative and significant impact on decision making. In equation 3 savings has positive and significant impact on social mobility results show the higher savings increase the social mobility. It gives women more freedom to make independent decisions about their social mobility i.e. whether she wants to invest her savings or purchase/sell the asset. Age has positive and significant impact on social mobility. Seniority gives more freedom of social mobility. In equation 6 savings has positive and significant impact on financial empowerment savings enhance the financial empowerment of the women. As savings transfer in property or savings account gives women more financial stability or economic empowerment strengthen her position in the house which is related to bargaining power (C. Doss, 2006). Share in income has negative and significant impact on financial empowerment. Age has positive and significant impact on financial empowerment. Overall results state that the savings has positive and significant impact on bargaining power and its components.

\section{Conclusion}

This empirical estimation is based on two main factors, education and income of the married working women. Considering the overall objective of the research, my hypothesis is that Socioeconomic factors do affect the bargaining power and its components which significantly contribute towards determining the bargaining power. Results show that the education and income have the positive and significant impact on bargaining power. Increase in income and higher level of education determines the bargaining power. As women gain more education and income, they are able to increase their bargaining power within the household. Women with higher level of income and education have more freedom and power to make decisions in house. Regarding outcomes male and female have different kind of choices and preferences. And also shows different outcomes if the women have more bargaining power. Dowry also plays an important and significant role for determining the bargaining power and financial empowerment. It shows that the assets brought to marriage enhance the women's status in household, women's high dowry strengthen her position in house and give her more power to negotiate which show, higher dowry is related with higher self-reported satisfaction of women. The policy makers are concerned about the bargaining power only because they assume that increasing women's bargaining power has the ability to give better results. While an academic branch of literature pays attention on testing the theoretical models of the household, and almost all the applied literature focuses on the understanding of intra-household bargaining as it is important for understanding how the different results are obtained.

Higher education enhances women status in societytherefore, the Government should take some serious steps regarding this problem and should have some adequate strategies to resolve this issue. Moreover, to overcome this problem it should provide more scholarships and open more technical institutes for the women. One of the major issues related to lower level of women education is the attitude and perception of the society towards the female education which prevented them to get high education, therefore, society needs some awareness related to female education. Cultural factors and old traditions are hinderers in the way of social values and social mobility. Society needs to change their prospective towards women by removing these obstacles and giving them freedom of voice and choice, so they can lead their life according to their will. 
Changing such social norms will create better position for women in the household as well in society.

\section{References}

Acharya, D. R., Bell, J. S., Simkhada, P., Van Teijlingen, E. R., \&Regmi, P. R. (2010). Women's autonomy in household decision-making: a demographic study in Nepal. Reproductive health, 7(1), 1-12.

Ali, T. S., Krantz, G., Gul, R., Asad, N., Johansson, E., \&Mogren, I. (2011). Gender roles and their influence on life prospects for women in urban Karachi, Pak0istan: a qualitative study. Global health action, 4(1), 7448.

Alkire, S., Meinzen-Dick, R., Peterman, A., Quisumbing, A., Seymour, G., \&Vaz, A. (2013).The women's empowerment in agriculture index. World development, 52, 71-91.

Arooj, S., Hussain, W., Arooj, A., Iqbal, A., Hameed, S., \&Abbasi, A. (2013).Paid Work \& Decision Making Power of Married Women Cross Sectional Survey of Muzaffarabad Azad State of Jammu \& Kashmir. Advances in Applied Sociology, 3(03), 165.

Ashraf, N., Karlan, D., \& Yin, W. (2010). Female empowerment: Impact of a commitment savings product in the Philippines. World development, 38(3), 333-344.

Beegle, K., Frankenberg, E., \& Thomas, D. (2001).Bargaining power within couples and use of prenatal and delivery care in Indonesia.Studies in family planning, 32(2), 130-146.

Breuer, A., \&Asiedu, E. (2017). Can gender-targeted employment interventions help enhance community participation? Evidence from urban Togo. World development, 96, 390-407.

Brown, P. H. (2009). Dowry and intrahousehold bargaining evidence from China.Journal of Human Resources, 44(1), 25-46.

Connelly, R., Roberts, K., \&Zheng, Z. (2010). The impact of circular migration on the position of married women in rural China.Feminist Economics, 16(1), 3-41.

De Brauw, A., Gilligan, D. O., Hoddinott, J., \& Roy, S. (2014). The impact of BolsaFamília on women's decision-making power.World development, 59, 487-504.

Desai, S., \&Andrist, L. (2010). Gender scripts and age at marriage in India. Demography, 47(3), 667-687.

Doss, C. (2006).The effects of intrahousehold property ownership on expenditure patterns in Ghana.Journal of African economies, 15(1), 149-180.

Doss, C. (2013).Intrahousehold bargaining and resource allocation in developing countries.The World Bank Research Observer, 28(1), 52-78.

Doss, C. R. (1996).Women's bargaining power in household economic decisions: Evidence from Ghana. Retrieved from

Doss, C. R., Deere, C. D., Oduro, A. D., \&Swaminathan, H. (2011).The gender asset and wealth gaps: evidence from Ecuador, Ghana, and Karnataka, India. Retrieved from

Fatima, D. (2014). Education, Employment, and Women's Say in Household Decision-Making in Pakistan.

Folbre, N. (2018). Developing care: Recent research on the care economy and economic development.

Ganle, J. K., Afriyie, K., \&Segbefia, A. Y. (2015). Microcredit: Empowerment and disempowerment of rural women in Ghana. World development, 66, 335-345.

Garikipati, S. (2008). The impact of lending to women on household vulnerability and women's empowerment: evidence from India. World development, 36(12), 2620-2642.

Guvuriro, S., \&Booysen, F. (2018).Family-type public goods and intra-household decision-making by co-resident South African couples.Review of Development Economics.

Haile, H. B., Bock, B., \&Folmer, H. (2012).Microfinance and female empowerment: Do institutions matter? Paper presented at the Women's studies international forum.

Hanson, S. (2009). Changing places through women's entrepreneurship. Economic geography, 85(3), 245-267. 
ILO.(2012). Global estimate of forced labour-Results and methodology.Geneva, June.

Jejeebhoy, S. J., \&Sathar, Z. A. (2001). Women's autonomy in India and Pakistan: the influence of religion and region. Population and development review, 27(4), 687-712.

Juhn, C., \& McCue, K. (2017). Specialization then and now: Marriage, children, and the gender earnings gap across cohorts. Journal of Economic Perspectives, 31(1), 183-204.

Kabeer, N. (1999). Resources, agency, achievements: Reflections on the measurement of women's empowerment. Development and change, 30(3), 435-464.

Kandiyoti, D. (1998). Afterword. Some Awkward Questions on Women and Modernity in Turkey: Princeton University Press.

Luke, N., \&Munshi, K. (2011). Women as agents of change: Female income and mobility in India. Journal of development economics, 94(1), 1-17.

Lundberg, S. J., \& Ward-Batts, J. (2000).Saving for retirement: Household bargaining and household net worth.Claremont McKenna College Robert Day School of Economics and Finance Research Paper(2004-03).

Mahmud, S., \&Tasneem, S. (2014).Measuring 'empowerment'using quantitative household survey data. Paper presented at the Women's Studies International Forum.

Mello, D., \&Schmink, M. (2017).Amazon entrepreneurs: Women's economic empowerment and the potential for more sustainable land use practices. Paper presented at the Women's Studies International Forum.

Miedema, S. S., Shwe, S., \&Kyaw, A. T. (2016). Social inequalities, empowerment, and women's transitions into abusive marriages: a case study from Myanmar. Gender \& Society, 30(4), 670-694.

Moghadam, Z. B., Khiaban, M. O., Esmaeili, M., \&Salsali, M. (2018). Review of the High Level of Education and Reduced Fertility in Iranian Women: Have Women Been Empowered.

Int. J. Womens Health Reprod. Sci, 20181(6), 2.

Mumtaz, Z., Salway, S., Waseem, M., \&Umer, N. (2003). Gender-based barriers to primary health care provision in Pakistan: the experience of female providers. Health policy and planning, 18(3), 261-269.

Ngunjiri, A. W. (2013). The Role of" Islamic feminism" in Somali Immigrant Women's Intra-and Extra-Household Bargaining Power and in Mitigating the Negative Effects of the Image Problem in their Integration in Norway. The University of Bergen,

OECD.(2018). Report. Retrieved from https://www.oecd.org/

Panda, P., \&Agarwal, B. (2005).Marital violence, human development and women's property status in India.World development, 33(5), 823-850.

Qian, N. (2008). Missing women and the price of tea in China: The effect of sex-specific earnings on sex imbalance.The Quarterly Journal of Economics, 123(3), 1251-1285.

Quisumbing, A., Estudillo, J., \&Otsuka, K. (2004). Land and Schooling: Transferring wealth across generations. Chapter 1, The Philippine Case (pp. 45-114). In: Johns Hopkins University Press: Maryland.

Quisumbing, A. R. (1994). Intergenerational transfers in Philippine rice villages: Gender differences in traditional inheritance customs. Journal of development economics, 43(2), 167-195.

Radel, C., Schmook, B., Haenn, N., \& Green, L. (2017).The gender dynamics of conditional cash transfers and smallholder farming in Calakmul, Mexico. Paper presented at the Women's Studies International Forum.

Reggio, I. (2011). The influence of the mother's power on her child's labor in Mexico.Journal of development economics, 96(1), 95-105.

Sanyal, P. (2009). From credit to collective action: The role of microfinance in promoting women's social capital and normative influence. American sociological review, 74(4), 529-550. 
Sarikhani, N. (2012). Individual Autonomy of Muslim Married Working Women in India and Iran: A Comparative Study of Mysore and Ahvaz Cities. Studies on Home and Community Science, 6(3), 127-138.

Sathar, Z. A., \&Kazi, S. (2000). Women's autonomy in the context of rural Pakistan.The Pakistan Development Review, 89-110.

SebertKuhlmann, A. K., Gullo, S., Galavotti, C., Grant, C., Cavatore, M., \&Posnock, S. (2017). Women's and health workers' Voices in open, inclusive communities and effective spaces (VOICES): measuring governance outcomes in reproductive and maternal health Programmes. Development Policy Review, 35(2), 289-311.

Shahid, U. (2017). Describing Determinants of Negotiation and Bargaining to Access and Utilize Resource Including Health among Immigrant Pakistani Women in US. International Journal of Gender and Women's Studies, 6(1), 34-50.

Thomas, D. (1994). Like father, like son; like mother, like daughter: Parental resources and child height.Journal of Human Resources, 950-988.

UN, W. (2018). Turning promises into action. Gender equality in the, 2030.

Winkvist, A., \&Akhtar, H. Z. (2000). God should give daughters to rich families only: attitudes towards childbearing among low-income women in Punjab, Pakistan. Social Science \& Medicine, 51(1), 73-81.

World Bank, G. (2017). World development indicators 2017: World Bank.

World Bank, G. (2019). The World Bank Annual Report 2019: Ending Poverty, Investing in Opportunity: The World Bank.

Yount, K. M. (2005). Women's family power and gender preference in Minya, Egypt.Journal of Marriage and Family, 67(2), 410-428.

Yount, K. M., \& Li, L. (2009).Women's “justification” of domestic violence in Egypt.Journal of Marriage and Family, 71(5), 1125-1140.

Yount, K. M., \& Li, L. (2010).Domestic violence against married women in Egypt.Sex roles, 63(5-6), 332-347.

Yusof, S. A., \&Duasa, J. (2010).Household decision-making and expenditure patterns of married men and women in Malaysia.Journal of family and economic issues, 31(3), 371-381.

Zaman, R. M., Stewart, S. M., \&Zaman, T. R. (2006). Pakistan: Culture, community, and familial obligations in a Muslim society.

Zhang, J., \& Chan, W. (1999). Dowry and Wife's Welfare: A Theotrical and Empirical Analysis. Journal of Political Economy, 107(4), 786-808. 